\title{
The Crystal and Molecular Structure of Acetatochlorobis(4-methylpyridine)oxovanadium (IV)
}

\author{
John D. Schupp and Stan A. Duraj* \\ Department of Chemistry, Cleveland State University, Cleveland, OH 44115 \\ Robert M. Richman* \\ Department of Science, Mount St. Mary's College, Emmitsburg, MD 21727 \\ Aloysius F. Hepp* \\ Thin-Film Group, NASA Glenn Research Center, Cleveland, OH 44135 \\ Phillip E. Fanwick \\ Department of Chemistry, Purdue University, West Lafayette, IN 47907
}

\begin{abstract}
The crystal and molecular structure of the title compound, $\mathrm{VOCl}\left(\mathrm{O}_{2} \mathrm{CCH}_{3}\right)(4-$ $\left.\mathrm{CH}_{3} \mathrm{C}_{5} \mathrm{H}_{4} \mathrm{~N}\right)_{2}$, has been determined by single-crystal $\mathrm{x}$-ray diffraction. The material crystallizes in the space group $\mathrm{P} \overline{1}(\# 2)$ with $\mathrm{a}=7.822(2), \mathrm{b}=8.023(1), \mathrm{c}=14.841(2) \AA, \alpha$ $=99.73(1), \beta=91.41(1)$, and $\gamma=117.13(1)$. The coordination geometry around the vanadium is a highly distorted octahedron. The molecule is remarkable for being a monomeric oxovanadium (IV) carboxylate. A generalized synthetic strategy is proposed for the preparation of oxovanadium (IV) monomers.
\end{abstract}

* - Address correspondence to these authors. publication. Because of changes that may be made before formal publication, this preprint is made available with the understanding that it will not be cited or reproduced without the permission of the author. 


\section{Introduction}

Oxovanadium (IV) may be the most stable diatomic ion known, so its complexes have been thoroughly studied. ${ }^{1}$ The discovery of two vanadoenzymes ${ }^{2,3}$ has spurred interest in the bioinorganic chemistry of vanadium. It has also been suggested that vanadium carboxylates might be good models for the active sites of peroxidases. 4

Metal carboxylates have been known since ancient times. They are interesting because the carboxylate may exist as a counterion, a unidentate ligand, a bidentate ligand, or a bridging ligand. ${ }^{5}$ Indeed, it is the latter mode that seems to be responsible for the abundance of oligomeric and polymeric oxovanadium (IV) carboxylates that have been reported. $^{5-8}$

The only other oxovanadium (IV) carboxylate that has been structurally characterized is $\mathrm{V}_{3}(\mathrm{O})_{3}(\mathrm{THF})\left(\mathrm{C}_{6} \mathrm{H}_{5} \mathrm{CO}_{2}\right)_{6}{ }^{6}$ Cotton, et. al. found that this trimer has virtual $\mathrm{C}_{2 \mathrm{v}}$ symmetry, rather than the expected $D_{3 h}$. The $\mathrm{V}_{3} \mathrm{O}$ core is unsymmetrical, with one $\mathrm{V}-\mathrm{O}$ bond length of $1.626(6) \AA$, while the other two are 2.344(7) $\AA$ and $2.452(6) \AA$. Five benzoate groups bridge pairs of vanadium atoms, while the sixth is unidentate.

Two monomeric oxovanadium (V) carboxylates have been structurally characterized. $^{4,9}$ We report the first oxovanadium (IV) carboxylate with a monomeric structure, the result of bidentate carboxylate coordination.

\section{Experimental}

\section{Synthesis}

The complex precipitated from 4-methylpyridine solution as a by-product of an attempt to prepare indium-vanadium clusters. In a drybox, a Schlenk tube was charged with $0.30 \mathrm{~g}$ ( $1.3 \mathrm{mmol})$ of indium(III) chloride, $0.28 \mathrm{~g}(1.8 \mathrm{mmol})$ of vanadium(III) chloride, and $0.60 \mathrm{~g}(7.3 \mathrm{mmol})$ of sodium acetate. The Schlenk tube was fitted with a septum, removed from the drybox, and connected to a double-manifold vacuum line. 
Under an increased flow of argon, $25 \mathrm{~mL}(260 \mathrm{mmol})$ of freshly distilled 4methylpyridine was added to the Schlenk tube via a syringe. Upon addition of the 4methylpyridine, and while stirring, the color of the solution turned dark purple. Under a rapid stream of argon, the septum was replaced with a glass stopper. The solution was then stirred at room temperature for 9 days during which time the solution remained dark purple.

Under argon, the reaction mixture was filtered through celite. The resultant dark purple filtrate was concentrated to one-half the original volume and stirred with $30 \mathrm{~mL}$ of freshly distilled hexane. Precipitation of the light purple crude product occurred. The solid was collected on a glass frit, washed with a $20 \mathrm{~mL}$ aliquot of fresh hexane, and dried under a vacuum for $12 \mathrm{~h}$. Recrystallization from 4-methylpyridine/hexane $(25 / 50 \mathrm{v} / \mathrm{v})$ yielded $0.4 \mathrm{~g}$ (1.2 mmol, $65 \%)$ of the title compound.

\section{Crystal Growth}

In a drybox, a Schlenk tube was charged with $0.4 \mathrm{~g}$ of the title compound. The Schlenk tube was fitted with a septum, removed from the drybox, and connected to a double-manifold vacuum line. Under an increased flow of argon, $25 \mathrm{~mL}$ of 4methylpyridine was added to the Schlenk tube via a syringe. The solution was stirred for $18 \mathrm{~h}$ at room temperature. During this time the solid completely dissolved producing a dark purple solution. The solution was filtered through celite, concentrated to approximately $12 \mathrm{~mL}$, and layered with $30 \mathrm{~mL}$ of hexane. Under positive pressure, the septum was replaced with a glass stopper and the Schlenk tube disconnected from the vacuum line. After several days at room temperature, blocky-type purple crystals, suitable for $\mathrm{x}$-ray analysis, were observed at the hexane/4-methylpyridine interface. IR (KBr disc, cm $\left.{ }^{-1}\right):$ 3067(w), 1620(s), 1502(m), 1458(s), 1210(w), 1060(sh), 1013(m), 983(m), 814(s), 651(w). 


\section{X-ray Crystallography}

A blue chunk of $\mathrm{C}_{14} \mathrm{H}_{17} \mathrm{ClN}_{2} \mathrm{O}_{3} \mathrm{~V}$ having approximate dimensions of $0.35 \mathrm{x} 0.31 \mathrm{x}$ $0.30 \mathrm{~mm}$ was mounted in a glass capillary in a random orientation. Cell constants and an orientation matrix for data collection were obtained from least-squares refinement, using the setting angles of 25 reflections in the range $19<\theta<22^{\circ}$. As a check on crystal quality, omega scans of several intense reflections were measured; the width at half-height was $0.49^{\circ}$ with a take-off angle of $3.0^{\circ}$ indicating good crystal quality. There were no systematic absences; the space group was determined to be $\mathrm{P} \overline{1}(\# 2)$.

The data were collected at a temperature of $293 \pm 1 \mathrm{~K}$ using the $\omega-2 \theta$ scan technique. The scan rate varied from 1 to $16 \%$ min (in omega). A total of 2117 reflections were collected, all of which were unique. Lorentz and polarization corrections were applied to the data. The linear absorption coefficient is $7.7 / \mathrm{cm}$ for $\mathrm{Mo}_{\alpha}$ radiation. An empirical absorption correction based on the method of Walker and Stuart ${ }^{10}$ was applied. Relative transmission coefficients ranged from 0.784 to 1.000 with an average value of 0.889 .

The structure was solved using the structure solution program SHELX-86. ${ }^{11}$ The remaining atoms were located in succeeding difference Fourier syntheses. Hydrogen atoms were located and added to the structure factor calculations but their positions were not refined. The structure was refined in full-matrix least-squares where the function minimized was $\Sigma w(|\mathrm{Fo}|-|\mathrm{Fc}|)^{2}$ and the weight $w$ is defined as per the Killean and Lawrence method with terms of 0.020 and $1.0{ }^{12}$

Scattering factors were taken from Cromer and Waber. ${ }^{13}$ Anomalous dispersion effects were included in $\mathrm{Fc} ;{ }^{14}$ the values for $\mathrm{f}$ and $\mathrm{f}^{\prime \prime}$ were those of Cromer. ${ }^{15}$ Only the 1725 reflections having intensities greater than 3.0 times their standard deviation were used in the refinements. The final cycle of refinement included 190 variable parameters and converged (largest parameter shift was 0.03 times the esd) with unweighted and weighted agreement factors as defined, respectively in equations (1) and (2). 


$$
\begin{aligned}
& \mathrm{R}=\Sigma\left|\mathrm{Fo}_{0}-\mathrm{Fc}\right| / \Sigma \mathrm{Fo}_{0}=0.038 \\
& \mathrm{R}_{\mathrm{w}}=\sqrt{ }\left(\Sigma \mathrm{w}\left(\mathrm{Fo}_{\mathrm{o}}-\mathrm{Fc}\right)^{2} / \Sigma \mathrm{W} \mathrm{Fo}^{2}\right)=0.050
\end{aligned}
$$

\section{Results and Discussion}

Crystallographic date for the title compound are given in Table I. The triclinic cell parameters and calculated volume are: $\mathrm{a}=7.822(2), \mathrm{b}=8.023(1), \mathrm{c}=14.841(2) \AA, \alpha=$ 99.73(1), $\beta=91.41(1), \gamma=117.13(1), V=811.4 \AA^{3}$. The molecular structure and numbering scheme of the compound are shown in Figure 1. Bond lengths and bond angles are given in Tables II and III.

The molecule shows significant distortion from octahedral geometry, due to both the $\pi$ bonding from the vanadyl oxygen and the small bite of the acetate ligand. Ignoring the methylpyridine rings and focusing on local symmetry at the vanadium atom, there is very nearly a plane of symmetry defined by $\mathrm{O}(1), \mathrm{V}(1), \mathrm{Cl}(1), \mathrm{O}(31), \mathrm{O}(32), \mathrm{C}(31)$, and $\mathrm{C}(32)$.

The VO bond length of the vanadyl moiety is $1.582(2) \AA$, which is quite typical. ${ }^{1,7,16,17}$ Recent ab initio calculations on $\mathrm{VO}(\mathrm{acac})_{2}$ confirm that the unpaired electron is completely localized in the metal $\mathrm{d}_{\mathrm{x}^{2}} \mathrm{y}^{2}$ orbital and suggest strong V-O bonding having partial triple bond character. ${ }^{18}$

Bond angles from the VO axis to equatorial ligands are smaller than usual. While bond angles ranging from $103^{\circ}$ to $110^{\circ}$ are most common in 5-coordinate oxovanadium (IV) complexes, ${ }^{16,17}$ and angles around $101^{\circ}$ are typical in 6-coordination, ${ }^{19}$ only the $\mathrm{O}(1)$ $\mathrm{V}(1)-\mathrm{Cl}(1)$ angle of $107.8^{\circ}$ falls within that range in our complex. By contrast, $\mathrm{O}(1)-\mathrm{V}(1)-$ $\mathrm{O}(31)$ is $98.2^{\circ}, \mathrm{O}(1)-\mathrm{V}(1)-\mathrm{N}(11)$ is $93.5^{\circ}$, and $\mathrm{O}(1)-\mathrm{V}(1)-\mathrm{N}(21)$ is $94.0^{\circ}$.

The adoption by 4-methylpyridine ligands of positions cis to the vanadyl oxygen is consistent with the conclusions of Caira, et. al., who inferred from infrared evidence that a number of substituted pyridines were coordinating in cis positions in $\mathrm{VO}(\mathrm{acac})_{2}$ adducts. $^{20}$ 
One acetate oxygen - $\mathrm{O}(32)-$ is trans to the vanadyl oxygen, while the other $\mathrm{O}(31)$ - is cis. Vanadium bonds to trans ligands are typically about $0.2 \AA$ longer than bonds to identical cis ligands (19), and that is indeed the case here, where $\mathrm{V}(1)-\mathrm{O}(31)$ is $2.044(3) \AA$ and $V(1)-O(32)$ is $2.237(3) \AA$.

The $\mathrm{O}(31)-\mathrm{V}(1)-\mathrm{O}(32)$ bond angle of $60.3(1)^{\circ}$ is substantially below the ideal octahedral angle of $90^{\circ}$ due to the strain of the four-membered ring. This strain also shows in the $\mathrm{V}(1)-\mathrm{O}(31)-\mathrm{C}(31)$ and $\mathrm{V}(1)-\mathrm{O}(32)-\mathrm{C}(31)$ bond angles of $95.2(2)^{\circ}$ and $86.7(2)^{\circ}$, well below the idealized $\mathrm{sp}^{2}$ angle of $120^{\circ}$. Vivanco's bidentate acetate of oxovanadium (V) also spans positions cis and trans to the oxo group. The comparable bond angles are $58.4(1)^{\circ}$, $98.4(3)^{\circ}$, and $83.4(3)^{\circ}$, respectively. ${ }^{9}$

\section{Conclusions}

The other oxovanadium (IV) carboxylates that have been structurally characterized are known or thought to be polynuclear. Cotton, et. al. obtained a vanadium trimer by combining $3 \mathrm{mmol} \mathrm{VCl}_{3} \bullet 3 \mathrm{THF}$ with $9 \mathrm{mmol}$ sodium benzoate in methylene chloride. ${ }^{6}$ Based on low magnetic susceptibilities, Casey et. al. proposed an oligormeric structure for oxovanadium (IV) carboxylates prepared either by heating hydrated vanadium (IV) oxide with the acid and anhydride in toluene or DMF, or by solvolysis of $\mathrm{VOCl}_{3}$ with a large excess of the acid. ${ }^{8}$ Patel, et. al. suggested the same structure, also because of low magnetic moments, for oxovanadium (IV) halobenzoates prepared by combining $10 \mathrm{mmol}$ of $\mathrm{VO}\left(\mathrm{SO}_{4}\right)$ with $20 \mathrm{mmol}$ of sodium halobenzoate in methanol/water. ${ }^{7}$

Then why did our compound form as a monomer when other oxovanadium (IV) carboxylates form polynuclear complexes? Perhaps because it formed in the coordinating solvent 4-methylpyridine. Oligomerization probably requires nucleophilic attack of a vanadyl oxygen or carboxylate oxygen on the vanadium atom of another molecule, but that can only happen if the second vanadium has an open coordination position. The negatively 
charged oxygen, chloride, and acetate ligands are unlikely to be very labile, so that means a 4-methylpyridine must come off to permit the attack. But if 4-methylpyridine is the solvent, an equilibrium will be established that leaves virtually no molecules coordinatively unsaturated. Thus, nucleophilic attack is effectively blocked.

This is consistent with the observations of Vivanco et. al. They prepared (mesityl) ${ }_{3} \mathrm{~V}-\mathrm{O}-\mathrm{V}(\text { mesityl) })_{3}$ in toluene, but this dimer was converted to the monomer $(\mathrm{mes})_{2} \mathrm{VO}(\mathrm{py})_{2}$ upon addition of pyridine. ${ }^{9}$

This suggests a generalized synthetic strategy for the preparation of vanadyl monomers with ligands that tend to form oligomers. Oxovanadium (IV) commonly achieves electroneutrality with 5-coordination, leaving the vanadium susceptible to further attack. The use of a strongly coordinating solvent, however, can tie up a sixth coordinating position, thus inhibiting subsequent reactivity. In the absence of a large excess of the bridging ligand, the equilibrium is pushed toward monomer.

\section{Supplementary Material}

Crystallographic data (excluding structure factors) for the structures in this paper have been deposited with the Cambridge Crystallographic Data Center as supplementary publication no. CCDC xxxxxx. Copies of the data can be obtained, free of charge, on application to CCDC, 12 Union Road, Cambridge CB2 1EZ, UK, (fax: +44 1223336033 or e-mail: deposit@ccdc.cam.ac.uk).

\section{Acknowledgment}

We gratefully acknowledge the National Aeronautics and Space Administration for its support through grants NCC3-162 (SAD), NCC3-720 (RMM and PEF) and the NASA Glenn Research Center Director's Discretionary Fund (AFH). 


\section{References}

1. J. Selbin, Chem. Rev. 65, 153, (1965).

2. E. de Boer, Y. van Kooyk, M. G. M. Tromp, H. Plat, and R. Wever, Biochim. Biophys. Acta, 869, 48, (1986).

3. R. L. Robson, R. R. Eady, T. H. Richardson, R. W. Miller, M. Hawkins, and J. R. Postgate, Nature (London) 322, 388, (1986).

4. D. Rehder, W. Priebsch, and M. von Oeynhausen, Angew. Chem. Intl. Ed. Engl. 28, $1221,(1989)$.

5. R. C. Mehrotra and R. Bohra, Metal Carboxylates. (Academic Press, New York, 1983).

6. F. A. Cotton, G. E. Lewis, and G. N. Mott, Inorg. Chem. 21, 3127, (1982).

7. K. S. Patel and O. A. Odunola, Synth. React. Inorg. Met.-Org. Chem. 20, 681, (1990).

8. A.T. Casey, B. S. Morris, E. Sinn, and J. K. Thackeray, Aust. J. Chem, 25, 1195, (1972).

9. M. Vivanco, J. Ruiz, C. Floriani, A. Chiesi-Villa, and C. Rizzoli, Organometallics 12, 1802, (1993).

10. N. Walker and D. Stuart, Acta Crystallogr. A39, 158, (1983).

11. G. M. Sheldrick, SHELX-86, Program for the Crystal Structure Determination (Institut fur Anorganische Chemie der Universitat Gottingen, F.R.G., 1986).

12. R. C. G. Killean and J. L. Lawrence, Acta Crystallogr. B25, 1750, (1969). 
13. D. T. Cromer and J. T. Waber, International Tables for X-Ray Crystallography, Vol. IV. (The Kynoch Press, Birmingham, England, 1974), Table 2.2B.

14. J. A. Ibers and W. C. Hamilton, Acta Crystallogr. 17, 781, (1964).

15. D. T. Cromer and J. T. Waber, International Tables for X-Ray Crystallography, Vol. IV. (The Kynoch Press, Birmingham, England, 1974), Table 2.3.1.

16. J. C. Dutton, G. D. Fallon, and K. S. Murray, Inorg. Chem. 27, 34, (1988).

17. D. Bruins and D. L. Weaver, Inorg. Chem. 9, 130, (1970).

18. S. Di Bella, G. Lanza, A. Gulino, and I. Fragala, Inorg. Chem. 35, 3885, (1996).

19. J. Chakravarty, S. Dutta, S. K. Chandra, P. Basu, and A. Chakravorty, Inorg. Chem. 32, 4249, (1993).

20. M. R. Caira, J. M. Haigh, and L. R. Nassimbeni, J. Inorg. Nucl. Chem. 34, 3171, (1972). 
Table I. Crystallographic Data for $\operatorname{VOCl}\left(\mathrm{O}_{2} \mathrm{CMe}\right)(4-p i c)_{2}$

\begin{tabular}{|l|l|}
\hline Molecular formula & $\mathrm{VClO}_{3} \mathrm{~N}_{2} \mathrm{C}_{14} \mathrm{H}_{17}$ \\
\hline Formula weight & 347.70 \\
\hline Temperature, $\mathrm{K}$ & 293 \\
\hline Wavelength, $\AA$ & 0.71073 \\
\hline Space group & $\mathrm{P} \overline{1}(\# 2)$ \\
\hline$a, \AA$ & $7.822(2)$ \\
\hline$b, \AA$ & $8.023(1)$ \\
\hline$c, \AA$ & $14.841(2)$ \\
\hline$\alpha$, deg & $99.73(1)$ \\
\hline$\beta$, deg & $91.41(1)$ \\
\hline$\gamma$, deg & $117.13(1)$ \\
\hline $\mathrm{V}, \AA^{3}$ & $811.4(5)$ \\
\hline $\mathrm{Z}$ & 2 \\
\hline $\mathrm{d}_{\text {calc }}, \mathrm{g} / \mathrm{cm}^{3}$ & 1.423 \\
\hline$\mu, \mathrm{cm}^{-1}$ & 7.66 \\
\hline Crystal size, mm & $0.35 \times 0.31 \times 0.30$ \\
\hline $2 \theta_{\text {range, deg }}$ & $4.00-45.00$ \\
\hline Scan method & $\omega-2 \theta$ \\
\hline Data / parameters & $2117 / 190$ \\
\hline No. obsd., I $\geq 3 \sigma(\mathrm{I})$ & 1725 \\
\hline $\mathrm{R}$ & 0.038 \\
\hline $\mathrm{R}_{\mathrm{w}}$ & 0.050 \\
\hline $\mathrm{GOF}$ & 1.603 \\
\hline Max. residual peak, $\AA^{-3}$ & 0.28 \\
\hline & \\
\hline
\end{tabular}


Table II. Bond Distances in Angstroms for $\operatorname{VOCl}\left(\mathrm{O}_{2} \mathrm{CMe}\right)(4-p i c)_{2}$

\begin{tabular}{|l|l|l|}
\hline Atom 1 & Atom 2 & Distance \\
\hline $\mathrm{V}(1)$ & $\mathrm{Cl}(1)$ & $2.320(1)$ \\
\hline $\mathrm{V}(1)$ & $\mathrm{O}(1)$ & $1.582(2)$ \\
\hline $\mathrm{V}(1)$ & $\mathrm{O}(31)$ & $2.044(3)$ \\
\hline $\mathrm{V}(1)$ & $\mathrm{O}(32)$ & $2.237(3)$ \\
\hline $\mathrm{V}(1)$ & $\mathrm{N}(11)$ & $2.154(3)$ \\
\hline $\mathrm{V}(1)$ & $\mathrm{N}(21)$ & $2.124(3)$ \\
\hline $\mathrm{O}(31)$ & $\mathrm{C}(31)$ & $1.267(5)$ \\
\hline $\mathrm{O}(32)$ & $\mathrm{C}(31)$ & $1.251(5)$ \\
\hline $\mathrm{N}(11)$ & $\mathrm{C}(12)$ & $1.322(5)$ \\
\hline $\mathrm{N}(11)$ & $\mathrm{C}(16)$ & $1.328(5)$ \\
\hline $\mathrm{N}(21)$ & $\mathrm{C}(22)$ & $1.338(5)$ \\
\hline $\mathrm{N}(21)$ & $\mathrm{C}(26)$ & $1.338(4)$ \\
\hline $\mathrm{C}(31)$ & $\mathrm{C}(32)$ & $1.489(6)$ \\
\hline $\mathrm{C}(12)$ & $\mathrm{C}(13)$ & $1.371(6)$ \\
\hline $\mathrm{C}(13)$ & $\mathrm{C}(14)$ & $1.366(7)$ \\
\hline $\mathrm{C}(14)$ & $\mathrm{C}(15)$ & $1.364(6)$ \\
\hline $\mathrm{C}(14)$ & $\mathrm{C}(17)$ & $1.501(6)$ \\
\hline $\mathrm{C}(15)$ & $\mathrm{C}(16)$ & $1.370(6)$ \\
\hline $\mathrm{C}(22)$ & $\mathrm{C}(23)$ & $1.369(5)$ \\
\hline $\mathrm{C}(23)$ & $\mathrm{C}(24)$ & $1.379(5)$ \\
\hline $\mathrm{C}(24)$ & $\mathrm{C}(25)$ & $1.378(5)$ \\
\hline $\mathrm{C}(24)$ & $\mathrm{C}(27)$ & $1.493(5)$ \\
\hline $\mathrm{C}(25)$ & $\mathrm{C}(26)$ & $1.368(5)$ \\
\hline & & \\
\hline
\end{tabular}


Table III. Bond Angles in Degrees for $\mathrm{VOCl}\left(\mathrm{O}_{2} \mathrm{CMe}\right)(4-\mathrm{pic})_{2}$

\begin{tabular}{|l|l|l|l|}
\hline Atom 1 & Atom 2 & Atom 3 & Angle \\
\hline $\mathrm{Cl}(1)$ & $\mathrm{V}(1)$ & $\mathrm{O}(1)$ & $107.8(1)$ \\
$\mathrm{Cl}(1)$ & $\mathrm{V}(1)$ & $\mathrm{O}(31)$ & $154.04(9)$ \\
$\mathrm{Cl}(1)$ & $\mathrm{V}(1)$ & $\mathrm{O}(32)$ & $93.78(8)$ \\
$\mathrm{Cl}(1)$ & $\mathrm{V}(1)$ & $\mathrm{N}(11)$ & $91.29(9)$ \\
$\mathrm{Cl}(1)$ & $\mathrm{V}(1)$ & $\mathrm{N}(21)$ & $88.82(9)$ \\
$\mathrm{O}(1)$ & $\mathrm{V}(1)$ & $\mathrm{O}(31)$ & $98.2(1)$ \\
$\mathrm{O}(1)$ & $\mathrm{V}(1)$ & $\mathrm{O}(32)$ & $158.4(1)$ \\
$\mathrm{O}(1)$ & $\mathrm{V}(1)$ & $\mathrm{N}(11)$ & $93.5(1)$ \\
$\mathrm{O}(1)$ & $\mathrm{V}(1)$ & $\mathrm{N}(21)$ & $94.0(1)$ \\
$\mathrm{O}(31)$ & $\mathrm{V}(1)$ & $\mathrm{O}(32)$ & $60.3(1)$ \\
$\mathrm{O}(31)$ & $\mathrm{V}(1)$ & $\mathrm{N}(11)$ & $87.6(1)$ \\
$\mathrm{O}(31)$ & $\mathrm{V}(1)$ & $\mathrm{N}(21)$ & $88.9(1)$ \\
$\mathrm{O}(32)$ & $\mathrm{V}(1)$ & $\mathrm{N}(11)$ & $84.9(1)$ \\
$\mathrm{O}(32)$ & $\mathrm{V}(1)$ & $\mathrm{N}(21)$ & $87.3(1)$ \\
$\mathrm{N}(11)$ & $\mathrm{V}(1)$ & $\mathrm{N}(21)$ & $172.1(1)$ \\
$\mathrm{V}(1)$ & $\mathrm{O}(31)$ & $\mathrm{C}(31)$ & $95.2(2)$ \\
$\mathrm{V}(1)$ & $\mathrm{O}(32)$ & $\mathrm{C}(31)$ & $86.7(2)$ \\
$\mathrm{V}(1)$ & $\mathrm{N}(11)$ & $\mathrm{C}(12)$ & $125.3(3)$ \\
$\mathrm{V}(1)$ & $\mathrm{N}(11)$ & $\mathrm{C}(16)$ & $118.6(2)$ \\
$\mathrm{C}(12)$ & $\mathrm{N}(11)$ & $\mathrm{C}(16)$ & $115.8(3)$ \\
$\mathrm{V}(1)$ & $\mathrm{N}(21)$ & $\mathrm{C}(22)$ & $121.5(2)$ \\
$\mathrm{V}(1)$ & $\mathrm{N}(21)$ & $\mathrm{C}(26)$ & $121.9(2)$ \\
$\mathrm{C}(22)$ & $\mathrm{N}(21)$ & $\mathrm{C}(26)$ & $116.7(3)$ \\
$\mathrm{O}(31)$ & $\mathrm{C}(31)$ & $\mathrm{O}(32)$ & $117.8(4)$ \\
$\mathrm{O}(31)$ & $\mathrm{C}(31)$ & $\mathrm{C}(32)$ & $120.2(4)$ \\
$\mathrm{O}(32)$ & $\mathrm{O}(31)$ & $\mathrm{C}(32)$ & $122.0(4)$ \\
$\mathrm{N}(11)$ & $\mathrm{C}(12)$ & $\mathrm{C}(13)$ & $123.3(4)$ \\
$\mathrm{C}(12)$ & $\mathrm{C}(13)$ & $\mathrm{C}(14)$ & $120.5(4)$ \\
$\mathrm{C}(13)$ & $\mathrm{C}(14)$ & $\mathrm{C}(15)$ & $116.4(4)$ \\
$\mathrm{C}(13)$ & $\mathrm{C}(14)$ & $\mathrm{C}(17)$ & $122.2(5)$ \\
$\mathrm{C}(15)$ & $\mathrm{C}(14)$ & $\mathrm{C}(17)$ & $121.3(5)$ \\
$\mathrm{C}(14)$ & $\mathrm{C}(15)$ & $\mathrm{C}(16)$ & $119.9(4)$ \\
$\mathrm{N}(11)$ & $\mathrm{C}(16)$ & $\mathrm{C}(15)$ & $123.9(4)$ \\
$\mathrm{N}(21)$ & $\mathrm{C}(22)$ & $\mathrm{C}(23)$ & $123.0(3)$ \\
$\mathrm{C}(22)$ & $\mathrm{C}(23)$ & $\mathrm{C}(24)$ & $120.6(3)$ \\
$\mathrm{C}(23)$ & $\mathrm{C}(24)$ & $\mathrm{C}(25)$ & $116.1(3)$ \\
$\mathrm{C}(23)$ & $\mathrm{C}(24)$ & $\mathrm{C}(27)$ & $122.9(4)$ \\
$\mathrm{C}(25)$ & $\mathrm{C}(24)$ & $\mathrm{C}(27)$ & $121.0(4)$ \\
$\mathrm{C}(24)$ & $\mathrm{C}(25)$ & $\mathrm{C}(26)$ & $120.7(3)$ \\
$\mathrm{N}(21)$ & $\mathrm{C}(26)$ & $\mathrm{C}(25)$ & $123.0(4)$ \\
\hline & & & \\
\hline
\end{tabular}




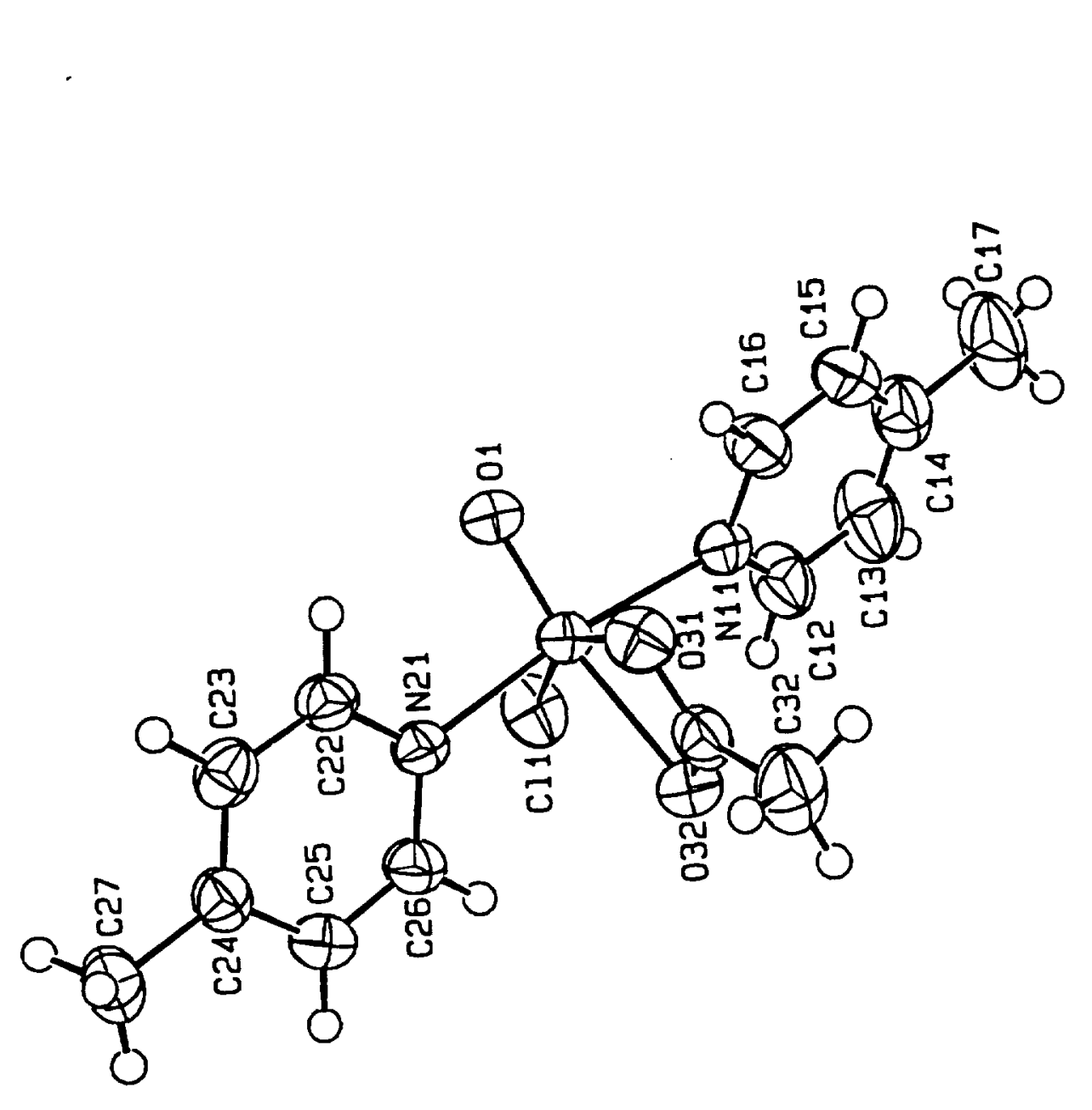

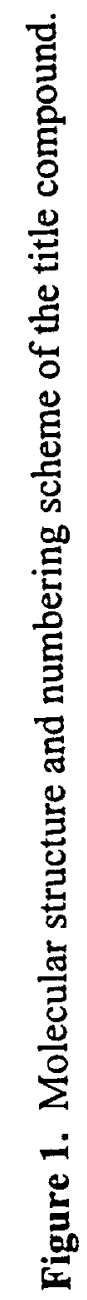

